\title{
Prevalence of common mental disorders among Brazilian workers: systematic review and meta-analysis
}

\author{
Prevalência de transtornos mentais comuns em trabalhadores \\ brasileiros: revisão sistemática e meta-análise
}

Diogo Henrique Constantino Coledam (https://orcid.org/0000-0001-6211-7069) ${ }^{1}$

Taciane Aurora Alves (https://orcid.org/0000-0002-6694-1562) ${ }^{1}$

Gustavo Aires de Arruda (https://orcid.org/0000-0002-9157-6114) ${ }^{2}$

Philippe Fanelli Ferraiol (https://orcid.org/0000-0002-3486-6473) ${ }^{3}$

${ }^{1}$ Instituto Federal de

Educação, Ciência e

Tecnologia de São Paulo.

R. Zélia de Lima Rosa

100 , Recanto das

Primaveras I. 18552-252

Boituva SP Brasil.

diogohcc@yahoo.com.br

${ }^{2}$ Escola de Enfermagem

Nossa Senhora das

Graças, Universidade de

Pernambuco. Recife PE

Brasil.

${ }^{3}$ Departamento de

Educação Física,

Universidade Estadual de

Londrina. Londrina PR

Brasil.

\begin{abstract}
The aim of the present study was to summarize the prevalence of common mental disorders (CMD) among Brazilian workers through a systematic review and meta-analysis. Searches were conducted in SciELO, LILACS, PubMed, Scopus, and Web of Science. Articles were included if they had; an observational design, a sample of Brazilian workers, used a validated instrument and cut-off to assess CMD, and provided the prevalence value. A random-effect meta-analysis using professional categories as subgroups and a meta-regression were conducted. In total, 89 studies were included, with a total of 56,278 workers from 26 professional categories. The overall pooled prevalence of CMD was 0.30 (95\%CI: 0.27-0.34), varying from 0.07 to 0.58 . Professional categories that presented higher prevalences of CMD were: Prostitutes 0.58 (95\%CI: 0.51-0.65), Social Educators 0.54 (95\%CI: 0.50-0.59), Banking Workers 0.45 (95\%CI: 0.44-0.47), Ragpickers 0.45 (95\%CI: 0.40-0.49), and Teachers 0.40 (95\%CI: $0.32-0.48$ ). No other variable in addition to profession was associated with prevalence of CMD in the meta-regression analysis. Workers from the most affected professional categories should be monitored to prevent social, occupational, and health impairment from CMD.
\end{abstract}

Key words Mental health, Occupational exposure, Epidemiology
Resumo Oobjetivo do presente estudo foi descrever a prevalência de transtornos mentais comuns (TMC) em trabalhadores brasileiros por meio de uma revisão sistemática e meta-análise. As buscas foram realizadas no SciELO, LILACS, PubMed, Scopus e Web of Science. Artigos observacionais, com amostra de trabalhadores brasileiros, que utilizaram instrumento e ponto de corte validados e que apresentaram valor de prevalência foram incluídos. Foram realizadas a meta-análise com efeito aleatório utilizando as categorias profissionais como subgrupos e a meta-regressão. Foram incluídos 89 estudos, com um total de 56.278 trabalhadores de 26 categorias profissionais. A prevalência global de TMC foi de 0,30 (IC95\%: 0,27-0,34), variando de 0,07 a 0,58. As categorias profissionais que apresentaram maiores valores de TMC foram: prostitutas 0,58 (IC95\%: 0,51-0,65), educadores sociais 0.54 (IC95\%: 0,50-0,59), bancários 0,45 (IC95\%: 0,44-0,47), coletores 0,45 (IC95\%: 0,40-0,49) e professores 0,40 (IC95\%: 0,32-0,48). Nenhuma outra variável além da profissão se associou ao TMC na meta-regressão. Trabalhadores das categorias profissionais mais afetadas por TMC devem ser monitorados para prevenir os prejuízos sociais, ocupacionais e de saúde associados aos TMC.

Palavras-chave Saúde mental, Exposição ocupacional, Epidemiologia 


\section{Introduction}

Common mental disorders are constituted by depressive and anxiety disorders ${ }^{1}$. Depression can be characterized as an absence of positive affect, low mood, and emotional, cognitive, physical, and behavioural symptoms ${ }^{2}$. With regard to the anxiety category, this refers to a group of mental disorders with symptoms of negative feelings and anxiety, including phobias, generalized anxiety, panic, social anxiety, and obsessive-compulsive and post-traumatic stress disorders ${ }^{1,2}$. The pooled prevalence of common mental disorders in the worldwide general population is high, varying from $17.6 \%$ at any one time point to $29.2 \%$ over a lifetime ${ }^{3}$. Consequently, a large proportion of the population is exposed to social, occupational, and physical health impairment, in addition to a higher mortality rate ${ }^{2}$.

The etiology of common mental disorders is multifactorial and complex and occupational aspects have received attention in the international literature. Work can have a positive effect on mental health. Unemployed people present a higher prevalence of depression compared to part-time employed or full-time employed individuals, due to income loss and consequent difficulties supporting their families. ${ }^{4}$. On the other hand, a poor work environment such as job strain, effort-reward imbalance, low job control, workplace bullying, job insecurity, overload, ambiguity, poor relationship with peers, and poor infrastructure are associated with a higher prevalence of common mental disorders among workers $^{5-7}$.

Due to the detrimental effects of work conditions on mental health, in Brazil a large number of studies have been conducted aiming to analyze the prevalence and factors associated with common mental disorders among a variety of occupational groups. In general, data indicate high variations in prevalence, since some studies indicate prevalences of common mental disorders exceeding $50 \%{ }^{8-18}$ while others report prevalences lower than $15 \%^{19-28}$. To our knowledge, no systematic reviews have been conducted aiming to describe the prevalence of common mental disorders among Brazilian workers. The absence of a pooled analysis limits the overview of methodological information regarding the published studies, as well as identification of professional groups for which investigation of the occurrence of common mental disorders has not been prioritized by the scientific community in Brazil. Moreover, this lack of information prevents understanding of which occupational categories present a higher risk for common mental disorders, with consequent difficulties creating specific public policies and guidelines to promote mental health in high-risk workers. In view of this, the aim of the present study was to conduct a systematic review and meta-analysis of the prevalence of common mental disorders among Brazilian workers.

\section{Methods}

\section{Background}

This is a systematic review and meta-analysis of studies published until May 2020. In the present study the outcome was the prevalence of any common mental disorder, assessed by instruments able to provide results on the suspicion of a common mental disorder, without discriminating which one (depression or anxiety disorders). The guideline of Preferred Reporting Items for Systematic Reviews and Meta-Analyse ${ }^{29}$ was adopted (Appendix 1 - available from: https://doi. org/10.48331/scielodata.RFVHDY).

\section{Eligibility criteria}

The question that guided the present systematic review was: What is the prevalence of common mental disorders among Brazilian workers? According to the PICOS model, the following eligibility criteria were adopted: Participants (P): Adult Brazilian workers; Intervention (I): Not applicable; Comparison (C): Not applicable; Outcome $(\mathrm{O})$ : Prevalence of common mental disorders assessed by a validated questionnaire and cut-off; Study (S): Cross-sectional or cohort (baseline data). The exclusion criteria were studies that do not report prevalence values or presented a pooled prevalence of common mental disorders of various work categories, samples with a group of participants that presented any diagnosed health disorder, absence of cutoff description and results from studies that used the same data set as a previous study (same year of data collection, sample size, and prevalence).

\section{Information sources and search strategies}

The search was conducted until May 2020 in the Scientific Electronic Library Online (SciELO), Latin American and Caribbean Center on Health Sciences Information (LILACS), MEDLINE (via 
PubMed), Scopus, and Web of Science databases. No restrictions for date and language were adopted. Manual searches were performed in specialized journals and in the reference list of included studies. The descriptors used were: "transtornos ment* comu*" OR "common mental disorders" OR “distúrbios psíquicos” OR "psychological distress" OR “distúrbios psíquicos menores” OR "transtornos psíquicos menores" OR "minor psychiatric disorders" OR "Minor psychic disorders" OR "transtornos psiquiátricos" OR "transtornos mentais menores" OR "minor mental disorders" AND prevalência OR prevalence OR frequência OR frequency OR levantamento OR survey AND Brasil OR Brazil. Searches were adapted according to each search mechanism (Appendix 2 - available from: https://doi.org/10.48331/scielodata. RFVHDY). In PubMed and Web of Science, the search was conducted using only descriptors in the English language.

\section{Study selection and data extraction}

Two independent reviewers (DHCC and TAA) identified duplicated results manually using a specific spreadsheet. After excluding the duplicates, the next step of manuscript selection was based on titles and abstracts, following the pre-defined inclusion and exclusion criteria. The remaining studies were assessed by reading the full text. When the results of the same study were found published in different papers (same sample, prevalence, and procedure information), the first published manuscript was included. In studies that informed an initial sample size for the whole study, however with a lower sample size for common mental disorders due to missing values, the sample size for common mental disorders was considered. Author, year of study, region, professional category, instrument and cut-off, sample, cases, and prevalence were extracted using a specific form. Disagreement regarding any information was resolved through consensus.

\section{Risk of bias assessment}

The risk of bias assessment was performed by two researchers (DHCC and PFF), both with experience in conducting research and assessing manuscripts on an epidemiological subject. Disagreements were decided through consensus. The instrument used was proposed by Hoy et al. ${ }^{30}$, a 10 -item checklist that contains dichotomous questions $(0=$ low risk or $1=$ high risk $)$ related to: national representativeness of sample; sampling procedures; non-response bias; data collection procedures; pre-defined case definition; validity and reliability of instruments; mode of data collection for all subjects; appropriate length of prevalence period; appropriate numerators and denominators for parameters. The score of the scale ranged from 0 to 10 and the cut-off values adopted to rate the risk of bias of included studies were: low (0-3), moderate (4-6), and high (7-10).

\section{Data synthesis and analysis}

The unadjusted prevalence was calculated for each included study. When only prevalence value and sample size were provided, the number of cases was calculated. For meta-analysis purposes, overall estimates were presented using the prevalence and 95\% confidence intervals (95\%CI). Single studies were included in a random-effect meta-analysis to pool the prevalence of all included studies. The comparison of prevalence according to each professional category was performed using subgroup analysis. Heterogeneity between studies was assessed using Cochran's Q (significance level at $\mathrm{P}<0.10)$, I-squared statistics $\left(\mathrm{I}^{2}\right)$, and Tau-squared $\left(\tau^{2}\right) . \mathrm{I}^{2}$ is the percentage of variability in the estimates which is attributable to heterogeneity between studies rather than to sampling error and $\tau^{2}$ describes the underlying between-study variability, measured in the same unit of measure as the outcome. Publication bias was assessed using visual inspection of the funnel plot of log-prevalence (x-axis) and sample size (y-axis). Sources of heterogeneity were assessed by random-effects meta-regressions, using the restricted maximum likelihood (REML) and Knapp-Hartung methods for estimation. Coefficients and 95\%CI are presented. For meta-regression purposes, due to the high number of professional categories, they were clustered into four groups according to prevalence values (Group $1=0.40$ to 0.58 ; Group $2=0.30$ to 0.38 ; Group $3=0.20$ to 0.28 ; Group $4=0.07$ to 0.18 ). Statistical procedures were conducted using the commands "metaprop" and "metareg" in Stata version 14 .

\section{Results}

\section{Study selection}

The flow diagram of study selection is summarized in Figure 1. A total of 2,745 articles were 
found through searches in five databases and two additional records from other sources. After duplicates had been removed, 1,482 references were analyzed and 1,330 were excluded after title and abstract screening. Subsequently, 152 full-texts were assessed for eligibility and reasons for additional exclusions were: studies that analyzed samples of more than one category of workers and did not provide stratified prevalence $(n=20)$; the use of the same data set $(n=13)$; did not describe cut-off of the instrument used (11); absence of prevalence $(\mathrm{n}=7)$; sample composed of sick workers $(\mathrm{n}=3)$; longitudinal design $(\mathrm{n}=3)$; and other reasons such as common mental disorders assessed through medical records and a sample composed of non-workers $(n=6)$, Appendix 3 (available from: https://doi.org/10.48331/scielodata.RFVHDY). All studies included in the systematic review were also included in the meta-analysis $(\mathrm{n}=89)$.

\section{Study characteristics}

The characteristics of the included studies are summarized in Table 1 (available from: https:// doi.org/10.48331/scielodata.RFVHDY). In some

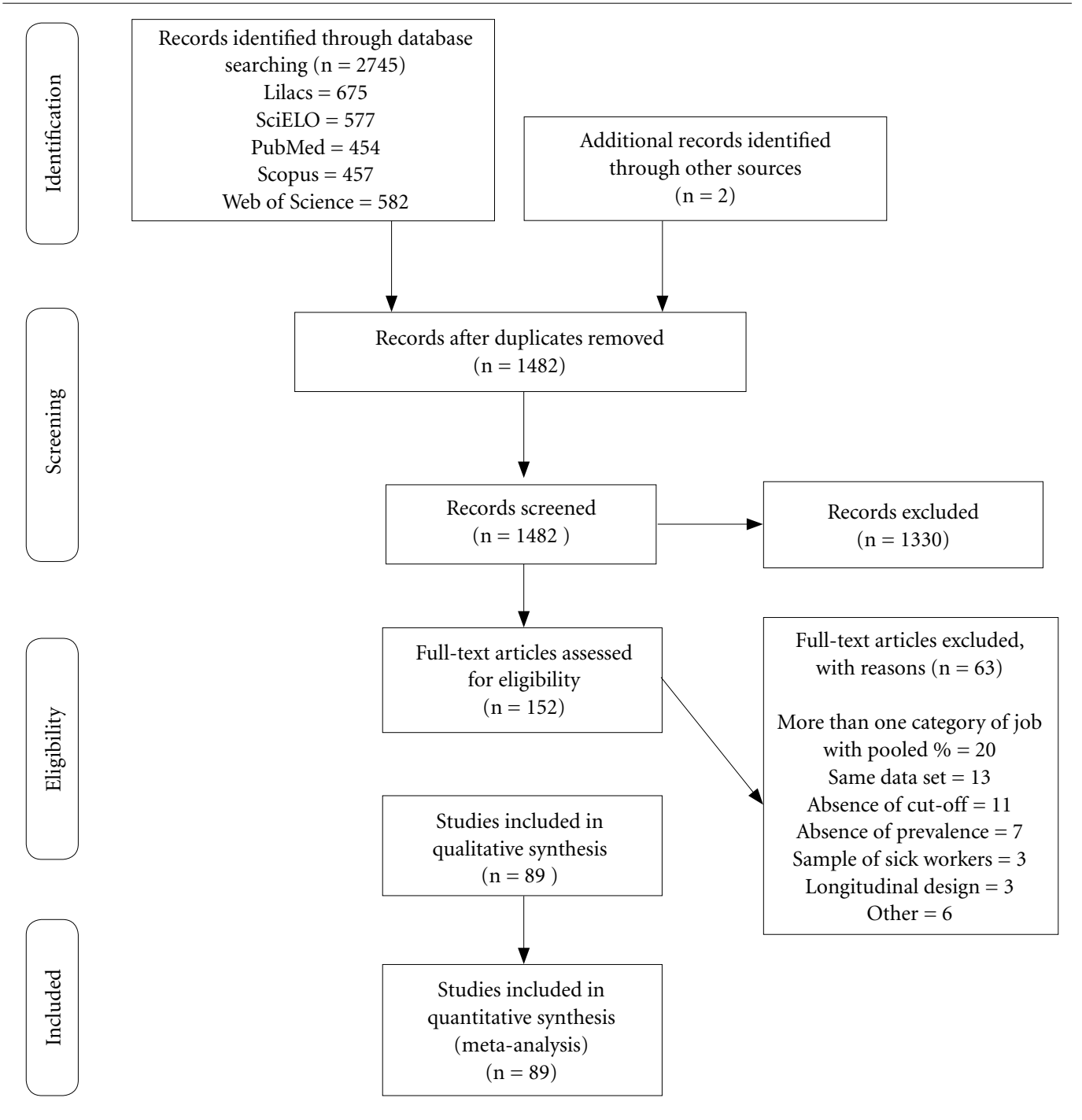

Figure 1. Flow chart of search and selection of studies. 
studies, data were presented stratified by two or more work categories. In these cases, the study was included in more than one category of work and consequently, for some variables (professional category and sample size), the frequency is higher than the number of included studies $(n=89)$. The included studies described common mental disorders in 26 work categories: teachers and professors

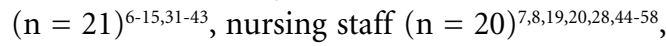
physicians $(n=9)^{7,19,21,28,46,59-62}$, community health agents $(\mathrm{n}=8)^{7,19,28,63-67}$, drivers and collectors $(\mathrm{n}=$ $4)^{22,23,68,69}$, police officers $(n=5)^{70-74}$, rural workers $(n=4)^{24,75-77}$, administrative technicians $(n=$ $4)^{19,28,78,79}$, prison agents $(n=3)^{80-82}$, banking workers $(\mathrm{n}=2)^{83,84}$, dentists $(\mathrm{n}=2)^{19,46}$, social educators $(\mathrm{n}=2)^{16,17}$, cleaning staff $(\mathrm{n}=2)^{85,86}$, and military personnel $(\mathrm{n}=2)^{87,88}$. One study was included for each of the professional categories: civil aviation pilots $^{25}$, civil aviation flight attendants ${ }^{89}$, fitness workers $^{26}$, salespeople ${ }^{90}$, nutritionists ${ }^{91}$, maritime workers $^{27}$, prostitutes $^{18}$, ragpickers $^{92}$, electricians ${ }^{93}$, poultry production workers ${ }^{94}$, managers ${ }^{95}$, and military firefighters ${ }^{96}$. With regard to period of data collection, 29 (32.6\%) studies were conducted between 1995 and 2008, 34 (38.2\%) between 2009 and 2012, 21 (23.6\%) after 2013, and 5 (5.6\%) did not describe this information. Studies were conducted mainly in the southeast 39 (43.8\%), south $25(28.1 \%)$, and northeast $21(23.6 \%)$. One study was conducted in the north, one had a national sample, and two included samples from two or more regions of Brazil. The self-report questionnaire (SRQ) was used by $77(86.5 \%)$ studies and $12(13.5 \%)$ used the Global Health Questionnaire (GHQ). The SRQ cut-off $\geq 7$ was the most frequently adopted in 40 studies $(44.9 \%) ; \geq 8$ in 11 (12.4\%), and $\geq 8$ for female and $\geq 6$ for male in 14 $(15.7 \%)$. Other cut-offs, including those for GHQ were used in $24(27.0 \%)$ studies. The distribution of studies according to sample size was: $\mathrm{n} \leq 299$ : $49(47.1 \%) ; \mathrm{n}=300$ to $599: 26(25.0 \%)$; and $\mathrm{n} \geq$ 600: 25 (24.0\%) studies.

\section{Risk of bias}

All the included studies presented either a low risk of bias, score 0 to 3 ( $n=73,82.0 \%)$, or a moderate risk of bias, score 4 to $6(n=16,18.0 \%)$. The classification of each study is presented in Table 1 and Appendix 4 (available from: https:// data.scielo.org/dataset.xhtml? persistentId=doi:10.48331/scielodata.RFVHDY).

The most common characteristics regarding risk of bias were: the study's target population was not a close representation of the national population $\mathrm{n}=88$ (98.9\%), non-response bias $\mathrm{n}=60(67.4 \%)$, did not use a random or census procedure for sample selection $\mathrm{n}=29$ (32.6\%), and sampling framework is not a true or close representation of the target population $\mathrm{n}=17$ (19.1\%).

\section{Synthesis of results}

The results of the meta-analysis are presented in Table 2 (available from: https://doi. org/10.48331/scielodata.RFVHDY). The overall prevalence was 0.30 (95\%CI: 0.27-0.34) with high heterogeneity presented by the included studies $\left(\mathrm{I}^{2}=98.67 \%, \tau^{2}=0.11, \mathrm{P}<0.01\right)$. The pooled prevalence, in decreasing order according to each professional category subgroup was: prostitutes 0.58 (95\%CI: 0.51-0.65); social educators 0.54 (95\%CI: 0.50-0.59); banking workers 0.45 (95\%CI: 0.44-0.47); ragpickers 0.45 (95\%CI: $0.40-0.49)$; teachers and professors 0.40 (95\%CI: 0.32 -0.48); nutritionists 0.38 (95\%CI: 0.32-0.44); military personnel 0.34 (95\%CI: $0.30-0.38)$; rural workers 0.34 (95\%CI: 0.15-0.53); community health agents 0.34 (95\%CI: $0.25-0.43)$; salespeople 0.31 (95\%CI: $0.22-0.42)$; civil aviation flight attendants 0.30 (95\%CI: $0.26-0.34)$; police officers 0.30 (95\%CI: $0.23-0.36)$; cleaning staff 0.28 (95\%CI: 0.22-0.34); nursing staff 0.27 (95\%CI: 0.22-0.33); administrative technicians 0.26 (95\%CI: 0.18-0.33); prison agents 0.26 (95\%CI: $0.20-0.31$ ); poultry production workers 0.24 (95\%CI: 0.22-0.27); managers 0.24 (95\%CI: 0.15-0.36); electricians 0.20 (95\%CI: 0.14-0.27); physicians 0.18 (95\%CI: 0.14-0.22); drivers and collectors 0.18 (95\%CI: 0.06-0.29); dentists 0.16 (95\%CI: 0.07-0.25); military firefighters 0.16 (95\%CI: 0.13-0.19); maritime workers 0.14 (95\%CI: 0.11-0.19); fitness workers 0.08 (95\%CI: $0.05-0.10)$; and civil aviation pilots 0.07 (95\% CI: 0.05-0.09). High variability attributed to heterogeneity was found in all work subgroups where it was possible to estimate this index ( $\mathrm{n}>3$ studies), values of $\mathrm{I}^{2}>82 \%, \mathrm{P}<0.01$. Between study variability revealed that the variance in the true effect sizes varied from $\tau^{2}=0.02$ to 0.19 , with higher values presented by studies with samples composed of teachers (0.14) and rural workers (0.19).

\section{Publication bias}

The funnel plot assessment revealed low asymmetry of CMD prevalence according to sample size, which indicates low probability of publication bias (Appendix 5 - available from: 
https://data.scielo.org/dataset.xhtml?persistentId=doi:10.48331/scielodata.RFVHDY).

\section{Additional analyses}

Sensitivity analysis was conducted to assess the effect of small $(\mathrm{n}<100)$ and large $(\mathrm{n}>1,500)$ studies on pooled prevalence estimates in each subgroup of professionals (Appendix 6 - available from: https://data.scielo.org/dataset.xhtm1?persistentId=doi:10.48331/scielodata. RFVHDY). No relevant effect of small or large studies on overall prevalence was found $(0.30,95 \% \mathrm{CI}$ : $0.27-.34,0.32, \quad 95 \% \mathrm{CI}: \quad 0.28-0.35$ and 0.30 , 95\%CI: 0.26-0.33) and heterogeneity remained stable across the analysis. In the subgroup analysis, an effect of larger studies was found only among banking workers and rural workers with an increase in pooled prevalence of 0.5 and 0.6 (Appendix 6).

Meta-regressions were performed to investigate potential sources of heterogeneity (Table 3). Professional categories were clustered into four groups according to prevalence value and the composition of each group is described in Table 4. Considering group four as the reference, the other three groups were positively associated with a higher prevalence of common mental disorders: group three $(0.07,95 \% \mathrm{CI}$ : $0.01-0.14)$, group two $(0.18,95 \%$ CI: $0.10-0.25)$, group one $(0.24$, 95\%CI: 0.16-0.32), all $\mathrm{P}<0.05$. Instrument, cutoff, sample size, region, risk of bias, and year of data collection were not associated with prevalence of common mental disorders, all $\mathrm{P}>0.05$.

\section{Discussion}

To our knowledge, this is the first study to conduct a systematic review and meta-analysis to investigate the prevalence of common mental disorders among Brazilian workers. The majority of professional categories analyzed presented a high pooled prevalence of common mental disorders $(>10 \%)$, and the highest pooled prevalence $(\geq$ $40 \%$ ) was found for prostitutes, social educators, banking workers, ragpickers, and teachers.

In Brazil, although prostitution is a regulated profession, the routine of this job is surrounded by risks such as physical and sexual violence, alcohol and drug use, abortion, confidentiality, and a high number of clients a week ${ }^{18}$, aspects that impose high mental distress on these professionals. Furthermore, these professionals are exposed to social stigma, which can emerge from socio-pow- er structures, and institutional, community, and individual sources and have a variety of consequences, including decreased mental wellness ${ }^{97}$. Social educators work providing support for individuals who are at risk or socially vulnerable, which in addition to low remuneration, impacts on the physical, moral, and psychological integrity of these workers ${ }^{16,17}$. Banking workers have a variety of occupational risks associated with common mental disorders, such as perception of negative interference from work in other areas of life, exposure to conflicts, the existence of individualism and professional disputes in the workplace, high demand, stress, low social support, and effort-reward imbalance ${ }^{83,84}$. Some inherent aspects of ragpicker routines contribute to impairment in mental health, such as working on dumps, riverbanks, and roadsides, a lack of personal protective equipment, the risk of traffic accidents, irregular work shifts, poor living conditions, social isolation, and discrimination ${ }^{92}$. Similarly to prostitutes, these professionals deal with social stigma and are commonly seen as the waste they pick up, things that are discarded and associated with dirt and grime. This is reinforced by characteristics such as old clothes, dirty hands, and skin marked by poverty. In addition, since these individuals pull carts through the streets, their image is often associated with that of an animal, which reflects in their marginal image in society ${ }^{98}$. The effects of work on the mental health of teachers are widely known, and it is notable that in the present review this is the professional category with the highest number of included studies. Problems related to the teaching profession are wide ranging and include a variety of health-related problems, social devaluation, overload, violence, role ambiguity, a low level of social support, low perceived self-efficacy, pressure, poor infrastructure and environment, low creativity and autonomy, and insufficient time for planning ${ }^{6,9,35-37}$.

One of the challenges related to common mental disorders among workers is to implement intervention and monitoring programs in some informal professions that are invisible to society, such as ragpickers and prostitutes, which could be achieved through implementation of public policies in partnership with specific associations and cooperatives. These organizations have proximity to the workers and databases with their contacts and are commonly consulted for research purposes ${ }^{18,92}$.

Although the professions cited above presented the highest pooled prevalence of common mental disorders, it is important to state that the 
Table 3. Meta-regression analysis of potential sources of heterogeneity.

\begin{tabular}{|c|c|c|c|}
\hline Subgroup & Estimate $(95 \% \mathrm{CI})$ & $\begin{array}{c}\text { Adjusted } \\
\text { coefficient }(95 \% \mathrm{CI}) \\
\end{array}$ & P-value \\
\hline \multicolumn{4}{|l|}{ Professional category } \\
\hline Group 4 & $0.16(0.12-0.20)$ & Reference & \\
\hline Group 3 & $0.27(0.24-0.30)$ & $0.07(0.01-0.14)$ & 0.038 \\
\hline Group 2 & $0.34(0.28-0.41)$ & $0.18(0.10-0.25)$ & $<0.001$ \\
\hline Group 1 & $0.43(0.36-0.49)$ & $0.24(0.16-0.32)$ & $<0.001$ \\
\hline \multicolumn{4}{|l|}{ Instrument } \\
\hline SRQ & $0.29(0.26-0.33)$ & Reference & \\
\hline GHQ & $0.38(0.31-0.44)$ & $-0.09(-0.20-0.03)$ & 0.126 \\
\hline \multicolumn{4}{|l|}{ Cut-offs } \\
\hline $\mathrm{SRQ} \geq 7$ & $0.30(0.25-0.35)$ & Reference & \\
\hline $\mathrm{SRQ} \geq 8$ & $0.34(0.24-0.44)$ & $-0.06(-0.15-0.03)$ & 0.181 \\
\hline SRQ: $F \geq 8$ and $M \geq 6$ & $0.25(0.19-0.31)$ & $-0.04(-0.11-0.03)$ & 0.270 \\
\hline Others including GHQ & $0.35(0.30-0.39)$ & $0.04(-0.05-0.12)$ & 0.401 \\
\hline \multicolumn{4}{|l|}{ Sample } \\
\hline Up to 299 & $0.30(0.23-0.36)$ & Reference & \\
\hline 300 to 599 & $0.30(0.24-0.35)$ & $-0.01(-0.04-0.07)$ & 0.667 \\
\hline$\geq 600$ & $0.33(0.27-0.39)$ & $0.04(-0.02-0.10)$ & 0.207 \\
\hline \multicolumn{4}{|l|}{ Region } \\
\hline South & $0.31(0.24-0.39)$ & Reference & \\
\hline Southeast & $0.33(0.29-0.37)$ & $0.06(-0.01-0.13)$ & 0.065 \\
\hline Northeast & $0.27(0.22-0.32)$ & $0.00(-0.07-0.07)$ & 0.950 \\
\hline North & $0.50(0.40-0.59)$ & $0.13(-0.11-0.38)$ & 0.276 \\
\hline$\geq$ two regions & $0.19(0.07-0.32)$ & $-0.06(-0.18-0.05)$ & 0.294 \\
\hline \multicolumn{4}{|l|}{ Risk of bias } \\
\hline Low & $0.30(0.27-0.33)$ & Reference & \\
\hline Moderate & $0.35(0.22-0.48)$ & $0.03(-0.04-0.10)$ & 0.443 \\
\hline \multicolumn{4}{|l|}{ Year of data collection } \\
\hline 1995 to 2008 & $0.31(0.26-0.36)$ & Reference & \\
\hline 2009 to 2012 & $0.26(0.22-0.30)$ & $-0.04(-0.10-0.02)$ & 0.191 \\
\hline 2013 to 2018 & $0.37(0.29-0.44)$ & $0.06(-0.01-0.13)$ & 0.105 \\
\hline Not-informed & $0.30(0.20-0.40)$ & $-0.03(-0.16-0.11)$ & 0.688 \\
\hline \multicolumn{4}{|c|}{$\begin{array}{l}\text { 95\%CI = 95\% confidence intervals; all variables were included in the adjusted model. SRQ = Self-Report Questionnaire; GHQ = } \\
\text { Global Health Questionnaire; F: female; M: male; Group 1: prostitutes, social educators, banking workers, ragpickers, teachers and } \\
\text { professors. Group 2: nutritionists, military personnel, rural workers, community health agents, salespeople, civil aviation flight } \\
\text { attendants and police officers. Group 3: cleaning staff, nursing staff, administrative technicians, prison agents, poultry production } \\
\text { workers, managers and electricians. Group 4: physicians, drivers and collectors, dentists, military firefighters, maritime workers, } \\
\text { fitness workers and civil aviation pilots. }\end{array}$} \\
\hline
\end{tabular}

Source: Authors.

prevalence of the outcome was high in most other professions. Of the 26 included studies, only two presented prevalences lower than $10 \%$, while 19 demonstrated prevalences higher than $20 \%$. Furthermore, curiously, some professional categories that are commonly cited as having a high risk of mental disorders due to work demands were not in the highest risk group. This is the case for police officers, military personnel, nursing staff, and prison agents, a result that partially cor- roborates a meta-analysis with workers from the United Kington ${ }^{99}$. The results of the present study indicate that a variety of other professions have a high prevalence of common mental disorders in addition to those already known. These results suggest that the mental health of the Brazilian workforce should be monitored to prevent or reduce risks related to common mental disorders. In addition, modifications in labor and social security rights should consider health impairment 


\begin{tabular}{|c|c|c|c|c|}
\hline 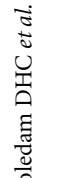 & Table 4. Groups of professional catego & ng order of prevalen & ommon mer & rders. \\
\hline & Professional categories & Pooled prevalence & 95\%CI & Group \\
\hline & Prostitutes & 0.58 & $0.51-0.65$ & \\
\hline & Social educators & 0.54 & $0.50-0.59$ & \\
\hline & Banking workers & 0.45 & $0.44-0.47$ & Group 1 \\
\hline & Ragpickers & 0.45 & $0.40-0.49$ & \\
\hline & Teachers and professors & 0.40 & $0.32-0.48$ & \\
\hline & Nutritionists & 0.38 & $0.32-0.44$ & \\
\hline & Military personnel & 0.34 & $0.30-0.38$ & \\
\hline & Rural workers & 0.34 & $0.15-0.53$ & \\
\hline & Community health agents & 0.34 & $0.25-0.43$ & Group 2 \\
\hline & Salespeople & 0.31 & $0.22-0.42$ & \\
\hline & Civil aviation flight attendants & 0.30 & $0.26-0.34$ & \\
\hline & Police officers & 0.30 & $0.23-0.36$ & \\
\hline & Cleaning staff & 0.28 & $0.22-0.34$ & \\
\hline & Nursing staff & 0.27 & $0.22-0.33$ & \\
\hline & Administrative technicians & 0.26 & $0.18-0.33$ & \\
\hline & Prison agents & 0.26 & $0.20-0.31$ & Group 3 \\
\hline & Poultry production workers & 0.24 & $0.22-0.27$ & \\
\hline & Managers & 0.24 & $0.15-0.36$ & \\
\hline & Electricians & 0.20 & $0.14-0.27$ & \\
\hline & Physicians & 0.18 & $0.14-0.22$ & \\
\hline & Drivers and collectors & 0.18 & $0.06-0.29$ & \\
\hline & Dentists & 0.16 & $0.07-0.25$ & \\
\hline & Military firefighters & 0.16 & $0.13-0.19$ & Group 4 \\
\hline & Maritime workers & 0.14 & $0.11-0.19$ & \\
\hline & Fitness workers & 0.08 & $0.05-0.10$ & \\
\hline & Civil aviation pilots & 0.07 & $0.05-0.09$ & \\
\hline
\end{tabular}

Souce: Authors.

of professions, since some reforms, as occurred recently in Brazil, can increase the occupational and health condition of workers ${ }^{100}$.

The present study also provides relevant information regarding the distribution of scientific research across Brazilian regions, professional categories, and instruments used. With respect to the number of studies, a considerable number of studies covering different regions of Brazil was found only for teachers and nursing staff. However, there was a lack of information in the central west and north regions even for these professional categories. Considering some professional categories, a low number of studies are available in the literature; only one study was available for each of 14 of the 26 professions. With regard to macro regions of Brazil, studies were mainly distributed in the southeast, south, and northeast respectively. Only one included study was conducted in the north and no studies were found from the central west. The higher number of research centers and
Universities in some regions could explain these differences. Furthermore, since teachers, nurses, and physicians are involved in health research, their respective professions become interesting for research. The SRQ was the most commonly used instrument followed by the GHQ, which reflects the accuracy of instruments and number of validation studies in the international literature ${ }^{101}$.

Additional analyses of meta-regressions were conducted to assess potential sources of heterogeneity among the included studies. Only groups of professions with similar prevalence values, as described in table 4, were associated with common mental disorders. Other potential sources of heterogeneity such as instrument, cut-off, region, sample size, date of publication, and risk of bias did not affect prevalence values. The absence of an influence of sample size on prevalence is relevant because there is great variability in the included studies and the effect of this variable on prevalence could be an important bias when an- 
alyzing prevalence studies ${ }^{102}$.

The interpretation of cut-offs adopted in studies is a methodological aspect that should be mentioned. Two of the most commonly cited validation studies on the $\mathrm{SRQ}^{103,104}$ suggest $7 / 8$ positive items as a cut-off with the Structured Clinical Interview as a reference criterion using an ROC curve. It was found that the best sensitivity and specificity (86.3 and $89.3 \%$ ) was 7.5 points for both sexes ${ }^{104}$. For this reason, a cut-off of $7 / 8$ is suggested for both sexes. A problem emerges since the SRQ includes 20 items that can result in any value from 0 to 20 but does not allow decimals in the score. It is not specified whether 7 or 8 points should be adopted as the cut-off, and some studies adopted 7 points $16,31,65,75,81,83$, some 8 points $s^{14,17,18,43,60}$, and some studies described only that $7 / 8$ was adopted ${ }^{6,67}$. The same occurred when analyzing the GHQ with the cut-off $3 / 4$, some studies adopted $3^{70,79,87,88,91}$ and others $4^{9,36,42,84}$. The divergence in interpretation of the cut-offs could affect the prevalence values, with more conservative cut-offs resulting in a lower prevalence. Nevertheless, this probably did not affect the present results since a pattern of cut-off use was not evidenced in specific professions and was not associated with common mental disorders in the meta-regression.

Some limitations of the present study should be considered when generalizing the results or planning future studies. Furthermore, studies that analyzed common mental disorders were considered, but not specific depressive and anxiety disorders. For this reason, key words related to diagnosed psychiatric diseases or other severe conditions were not adopted and, consequently, the results cannot be generalized for specific mental disorders ${ }^{2}$. Since there are only one or two studies for the majority of professional categories, the analysis of factors associated with heterogeneity inside each subgroup was impracticable.

\section{Conclusions}

The pooled prevalence of common mental disorders among Brazilian workers of 26 professional categories was high $(30 \%)$. The professional categories prostitutes, social educators, banking workers, ragpickers, and teachers presented the highest prevalences ( 40 to $58 \%$ ) while physicians, drivers and collectors, dentists, military firefighters, maritime workers, fitness workers, and civil aviation pilots presented the lowest prevalences (7 to $18 \%$ ). The results suggest that workers from the most affected professional categories should be monitored to prevent social, occupational, and health impairment from CMD. Future studies should consider professional categories and regions of Brazil that have received little attention to date.

\section{Collaborations}

Coledam DHC worked on the conception and design of the study, searching, data extraction, statistical analysis and interpretation, drafting, critical review and final approval of the manuscript. Aurora TA performed searching, data extraction, interpretation of data, critical review and final approval of the manuscript. Arruda GA performed substantial contribution on interpretation, drafting, critical review and final approval of the manuscript. Ferraiol PH contributed on data analysis and interpretation, drafting, critical review and final approval of the manuscript. 


\section{References}

1. World Health Organization (WHO). Depression and Other Common Mental Disorders: Global Health Estimates. Geneva: WHO; 2017.

2. Kendrick T, Pilling S. Common mental health disorders - identification and pathways to care: NICE clinical guideline. Br J Gen Pract 2012; 62(594):47-49.

3. Steel Z, Marnane C, Iranpour C, Chey T, Jackson JW, Patel V, Silove D. The global prevalence of common mental disorders: a systematic review and meta-analysis 1980-2013. Int J Epidemiol 2014; 43(2):476-493.

4. Perreault M, Touré EH, Perreault N, Caron J. Employment status and mental health: Mediating roles of social support and coping strategies. Psychiatr Q 2017; 88(3):501-514.

5. Rugulies R, Aust B. Work and mental health: what do we know and how can we intervene?. Scand J Work Environ Health 2019; 45(6):529-532.

6. Carlotto MS, Câmara SG. Prevalence and risk factors of common mental disorders among teachers. JWOP 2015; 31(3):201-206.

7. Dilélio AS, Facchini LA, Tomasi E, Silva SM, Thumé E, Piccini RX, Silveira DS, Maia MFS, Osório A, Siqueira FV, Jardim VMR, Lemões MAM, Borges CLS. Prevalência de transtornos psiquiátricos menores em trabalhadores da atenção primária à saúde das regiões Sul e Nordeste do Brasil. Cad Saude Publica 2012; 28(3):503-514.

8. Nascimento JOV, Santos JD, Meira KC, Pierin AMG, Souza-Talarico JN. Shift work of nursing professionals and blood pressure, burnout and common mental disorders. Rev Esc Enferm USP 2019; 53:e03443.

9. Gasparini SM, Barreto SM, Assunção AA. Prevalência de transtornos mentais comuns em professores da rede municipal de Belo Horizonte, Minas Gerais, Brasil. Cad Saude Publica 2006; 22(12):2679-2691.

10. Jardim R, Barreto SM, Assunção AÁ. Condições de trabalho, qualidade de vida e disfonia entre docentes. Cad Saude Publica 2007; 23(10):2439-2461.

11. Monteiro JK, Brun LG, Santos AS, Tundis AGO, Cardon SB. Distúrbios psiquiátricos menores e fatores associados em professores do ensino privado do Rio Grande do Sul/Brasil. Contextos Clínicos 2019; 12(3):843-862.

12. Reis EJFBD, Carvalho FM, Araújo TMD, Porto LA, Silvany Neto AM. Trabalho e distúrbios psíquicos em professores da rede municipal de Vitória da Conquista, Bahia, Brasil. Cad Saude Publica 2005; 21(5):14801490.

13. Tostes MV, Albuquerque GSCD, Silva MJDS, Petterle RR. Sofrimento mental de professores do ensino público. Saúde Debate 2018; 42(116):87-99.

14. Porto LA, Carvalho FM, Oliveira NFD, Silvany Neto AM, Araújo TMD, Reis EJFBD, Delcor NS. Associação entre distúrbios psíquicos e aspectos psicossociais do trabalho de professores. Rev Saude Publica 2006; 40(5):818-826.

15. Medeiros AM, Assunção AA, Barreto SM. Absenteeism due to voice disorders in female teachers: a public health problem. Int Arch Occup Environ Health 2012; 85(8):853-864.
16. Greco PBT, Magnago TSBDS, Lopes LFD, Prochnow A, Tavares JP, Viero NC. Estresse psicossocial e distúrbios psíquicos menores em agentes socioeducadores. Rev Lat Am Enfermagem 2012; 20(5):971-979.

17. Romero DL, Akiba HT, Dias ÁM, Serafim ADP. Transtornos mentais comuns em educadores sociais. J Bras Psiquiatr 2016; 65(4):322-329.

18. Vidal CEL, Amara B, Ferreira DP, Dias IMF, Vilela LA, Franco LR. Preditores de prováveis transtornos mentais comuns (TMC) em prostitutas utilizando o Self-Reporting Questionnaire. J Bras Psiquiatr 2014; 63(3):205-212.

19. Carvalho DBD, Araújo TMD, Bernardes KO. Transtornos mentais comuns em trabalhadores da Atenção Básica à Saúde. Rev Bras Saude Ocup 2016; 41:e17.

20. Souza MNM, Martins Júnior DF, Silva MV. Trabalho e saúde dos profissionais de enfermagem de um hospital especializado de Feira de Santana, Bahia. Revista Baiana de Saúde Pública 2011; 35(Suppl. 1):38-54.

21. Neves BS, Pinheiro TMM. Epidemiological and occupational profile of anesthesiologists practicing in Belo Horizonte, Minas Gerais-Brazil, in 2010. Braz J Anesthesiol 2012; 62(5):618-624.

22. Moura Neto AB, Silva MC. Diagnóstico das condições de trabalho, saúde e indicadores do estilo de vida de trabalhadores do transporte coletivo da cidade de Pelotas-RS. Rev Bras Ativ Fis Saúde 2012; 17(5):347-358.

23. Ulhôa MA, Marqueze EC, Lemos LC, Silva LGD, Silva AA, Nehme P, Ficher FM, Moreno CRDC. Distúrbios psíquicos menores e condições de trabalho em motoristas de caminhão. Rev Saude Publica 2010; 44(6):1130-1136.

24. Faria NMX, Fassa AG, Meucci RD, Fiori NS, Miranda VI. Occupational exposure to pesticides, nicotine and minor psychiatric disorders among tobacco farmers in southern Brazil. Neurotoxicology 2014; 45:347-354.

25. Feijó D, Luiz RR, Camara VM. Common mental disorders among civil aviation pilots. Aviat Space Environ Med 2012; 83(5):509-513.

26. Hartwig T, Silva M, Reichert F, Rombaldi A. Condições de saúde de trabalhadores de academias da cidade de Pelotas-RS: um estudo de base populacional. Rev Bras Ativ Fis Saúde 2012; 17(6):500-511.

27. Silva JLL, Moreno RF, Soares RS, Ameida JA, Daher DV, Teixeira ER. Prevalência de transtornos mentais comuns entre trabalhadores marítimos do Rio de Janeiro. J Res Fundam Care Online 2017; 9(3):676-681.

28. Faria NMX, Klosinski RFS, Rustick G, Oliveira LDM. Saúde mental dos trabalhadores da saúde pública em Bento Gonçalves, no Rio Grande do Sul. Rev Bras Med Trab 2018; 16(2):145-157.

29. Galvão TF, Pansani TSA, Harrad D. Principais itens para relatar Revisões sistemáticas e Meta-análises: a recomendação PRISMA. Epidemiol Serv Saude 2015; 24(2):335-342.

30. Hoy D, Brooks P, Woolf A, Blyth F, March L, Bain C, Baker P, Smith E, Buchbinder R. Assessing risk of bias in prevalence studies: modification of an existing tool and evidence of interrater agreement. J Clin Epidemiol 2012; 65(9):934-939. 
31. Baldaçara L, Silva AF, Castro JGD, Santos GDCA Common psychiatric symptoms among public school teachers in Palmas, Tocantins, Brazil. An observational cross-sectional study. Sao Paulo Med J 2015; 133(5): 435-438.

32. Ceballos AGDCD, Santos GB. Fatores associados à dor musculoesquelética em professores: aspectos sociodemográficos, saúde geral e bem-estar no trabalho. Rev Bras Epidemiol 2015; 18(3):702-715.

33. Coledam DHC, Silva YM. Prescribed medication use among elementary teachers: Prevalence and associated factors. Cien Saude Colet 2020; 25(12):5051-64.

34. Delcor NS, Araújo TM, Reis EJ, Porto LA, Carvalho FM, Silva MO, Barbalho L, Andrade JMD. Condições de trabalho e saúde dos professores da rede particular de ensino de Vitória da Conquista, Bahia, Brasil. Cad Saude Publica 2004; 20(1):187-196.

35. Ferreira RC, Silveira APD, Sá MABD, Feres SDBL, Souza JGS, Martins AMEDBL. Transtorno mental e estressores no trabalho entre professores universitários da área da saúde. Trab Educ Saude 2015; 13(Suppl. 1):135-155.

36. Machado LC, Limongi JE. Prevalência e fatores relacionados a transtornos mentais comuns entre professores da rede municipal de ensino, Uberlândia, Minas Gerais, Brasil. Rev Bras Med Trab 2019; 17(3):325-334.

37. Rocha LM, Souza, LDM. Voice Handicap Index associated with common mental disorders in elementary school teachers. J Voice 2013; 27(5):595-602.

38. Silva LGD, Silva MCD. Condições de trabalho e saúde de professores pré-escolares da rede pública de ensino de Pelotas, RS, Brasil. Cien Saude Colet 2013; 18(11):3137-3146

39. Silvany Neto AM, Araújo TMD, Kawalkievicz C, Lima BGDC, Dutra FRD, Paiva LC, Sarno MM. Condições de trabalho e saúde em professores da rede particular de ensino na Bahia: estudo piloto. Revista Brasileira de Sáude Ocupacional 1998; 24(91/92):115-124.

40. Souza CLD, Carvalho FM, Araújo TMD, Reis EJFBD, Lima VMC, Porto LA. Fatores associados a patologias de pregas vocais em professores. Rev Saude Publica 2011; 45(5):914-921.

41. Tavares JP, Beck CLC, Magnago TSBS, Zanini RR, Lautert L. Distúrbios psíquicos menores em enfermeiros docentes de universidades. Rev Lat Am Enfermagem 2012; 20(1):08 telas.

42. Neme GGS, Limongi JE. Prevalência e fatores relacionados a transtornos mentais comuns entre professores universitários de uma universidade federal brasileira. Hygeia 2019; 15(32):112-120.

43. Lyra GFD, Assis SGD, Njaine K, Oliveira RDVCD, Pires TDO. A relação entre professores com sofrimento psíquico e crianças escolares com problemas de comportamento. Cien Saude Colet 2009; 14(2):435-444.

44. Araújo TM, Aquino E, Menezes G, Santos CO, Aguiar L. Aspectos psicossociais do trabalho e distúrbios psíquicos entre trabalhadoras de enfermagem. Rev Saude Publica 2003; 37(4):424-433.

45. Assunção AA, Pimenta AM. Satisfação no trabalho do pessoal de enfermagem na rede pública de saúde em uma capital brasileira. Cien Saude Colet 2020; 25(1):169-180
46. Barbosa GB, Correia AKS, Oliveira LDMM, Santos VDC, Ferreira SMDS, Martins Júnior DF, Nascimento Sobrinho CL. Trabalho e saúde mental dos profissionais da Estratégia Saúde da Família em um município do Estado da Bahia, Brasil. Rev Bras Saude Ocup 2012; 37(126):306-315.

47. Diniz TB, Silva-Costa A, Griep RH, Rotenberg L. Minor psychiatric disorders among nursing workers-is there an association with current or former night work?. Work 2012; 41(Suppl. 1):2887-2892.

48. Kirchhof ALC, Magnago TSBDS, Camponogara S, Griep RH, Tavares JP, Prestes FC, Paes LG. Condições de trabalho e características sociodemográficas relacionadas à presença de distúrbios psíquicos menores em trabalhadores de enfermagem. Texto \& Contexto -Enfermagem 2009; 18(2):215-223.

49. Lua I, Araújo TMD, Santos KOB, Almeida MMGD Factors associated with common mental disorders among female nursing professionals in primary health care. Psicol Reflex Crit 2018; 31:20.

50. Magnago TSBDS, Prochnow A, Urbanetto JDS, Greco PBT, Beltrame M, Luz EMFD. Relação entre capacidade para o trabalho na enfermagem e distúrbios psíquicos menores. Texto \& Contexto-Enfermagem 2015; 24(2):362-370.

51. Nascimento DSS, Barbosa GB, Santos CLC, Martins Júnior DF, Nascimento Sobrinho, CL. Prevalência de distúrbio psíquico menor e fatores associados em enfermeiros intensivistas. Rev Baiana Enferm 2019; 33:e28091.

52. Oliveira EB, Silva SRCS, Sora AB, Oliveira TS, Valério RL, Dias LBS. Distúrbios psíquicos menores em trabalhadores de Enfermagem de um hospital psiquiátrico. Rev Esc Enferm USP 2020; 54: e03543.

53. Pinhatti EDG, Ribeiro RP, Soares MH, Martins JT, Lacerda MR. Distúrbios psíquicos menores na enfermagem: prevalência e fatores associados. Rev Bras Enferm 2018; 71 (Suppl. 5):2176-2183.

54. Rotenberg L, Silva-Costa A, Griep RH. Mental health and poor recovery in female nursing workers: a contribution to the study of gender inequities. Rev Panam Salud Publica 2014; 35(3):179-185.

55. Silva JLLD, Soares RDS, Costa FDS, Ramos DDS, Lima FB, Teixeira LR. Fatores psicossociais e prevalência da síndrome de burnout entre trabalhadores de enfermagem intensivistas. Rev Bras Ter Intensiva 2015 27(2):125-133.

56. Sousa KHJF, Lopes DDP, Tracera GMP, Abreu AMM, Portela LF, Zeitoune RCG. Trastornos mentales comunes entre trabajadores de enfermería de un hospital psiquiátrico. Acta Paul Enferm 2019; 32(1):1-10.

57. Urbanetto JS, Magalhães MCC, Maciel VO, Sant'Anna VM, Gustavo AS, Poli-de-Figueiredo CE, Magnago TSBS. Estresse no trabalho segundo o modelo demanda-controle e distúrbios psíquicos menores em trabalhadores de enfermagem. Rev Esc Enferm USP 2013; 47(5):1180-1186.

58. Santos FFD, Brito MFSF, Pinho LD, Cunha FO, Rodrigues Neto JF, Fonseca ADG, Silva CSDO. Transtornos mentais comuns em técnicos de Enfermagem de um hospital universitário. Rev Bras Enferm 2020; 73(1):e20180513. 
59. Assunção AA, Machado CJ, Prais HAC, Araujo TM. Working conditions and common mental disorders in physicians in Brazil. Occup Med 2013; 63(3):234-237.

60. Cabana MCF, Ludermir AB, Silva ER, Ferreira MLL, Pinto MER. Transtornos mentais comuns em médicos e seu cotidiano de trabalho. J Bras Psiquiatr 2007;56(1):33-40.

61. Ribeiro RBN, Assunção AA, Araújo TM. Factors associated with job satisfaction among public-sector physicians in Belo Horizonte, Brazil. Int J Health Serv 2014; 44(4):787-804.

62. Nascimento Sobrinho CL, Carvalho FM, Bonfim TAS, Cirino CAS, Ferreira IS. Condições de trabalho e saúde mental dos médicos de Salvador, Bahia, Brasil. Cad Saude Publica 2006; 22(1):131-140.

63. Alcântara MAD, Assunção AA. Influência da organização do trabalho sobre a prevalência de transtornos mentais comuns dos agentes comunitários de saúde de Belo Horizonte. Rev Bras Saude Ocup 2016; 41:e2.

64. Fernandes A, Stein AT, Giugliani C. Conhecimentos dos agentes comunitários de saúde sobre crack e outras drogas. Rev Bras Med Fam Comunidade 2015; 10(34):1-10.

65. Knuth BS, Silva RAD, Oses JP, Radtke VA, Cocco RA, Jansen K. Mental disorders among health workers in Brazil. Cien Saude Colet 2015; 20(8):2481-2488.

66. Santos, AMVS, Lima CA, Messias RB, Costa FM, Brito, MFSF. Transtornos mentais comuns: prevalência e fatores associados entre agentes comunitários de saúde. Cad Saúde Colet 2017; 25(2):160-168.

67. Silva ATCD, Menezes PR. Esgotamento profissional e transtornos mentais comuns em agentes comunitários de saúde. Rev Saude Publica 2008; 42(5): 921-929.

68. Assunção AA, Silva LS. Condições de trabalho nos onnibus e os transtornos mentais comuns em motoristas e cobradores: Região Metropolitana de Belo Horizonte, Minas Gerais, Brasil, 2012. Cad Saude Publica 2013; 29(12):2473-2486.

69. Cavagioni LC, Pierin AMG, Batista KDM, Bianchi ERF, Costa ALS. Agravos à saúde, hipertensão arterial e predisposição ao estresse em motoristas de caminhão. Rev Esc Enferm USP 2009; 43(S2):1267-1271.

70. Godinho EL, Farias LC, Aguiar JCA, Martelli Júnior H, Bonan PRF, Ferreira RC, Paula AMB, Martins AMEBL, Guimaraes ALS. No association between periodontal disease and GHQ-12 in a Brazilian Police population. Med Oral Patol Oral Cir Bucal 2011; 16(6):e857-e863.

71. Souza ERD, Minayo MCDS, Silva JG, Pires TDO. Fatores associados ao sofrimento psíquico de policiais militares da cidade do Rio de Janeiro, Brasil. Cad Saude Publica 2012; 28(7):1297-1311.

72. Pinto LW, Figueiredo AEB, Souza ERD. Sofrimento psíquico em policiais civis do Estado do Rio de Janeiro. Cien Saude Colet 2013; 18(3):633-644.

73. Minayo MCDS, Assis SGD, Oliveira RVCD. Impacto das atividades profissionais na saúde física e mental dos policiais civis e militares do Rio de Janeiro (RJ, Brasil). Cien Saude Colet 2011;16(4):2199-2209.

74. Leite LC, Lucena NC, Valença MM, Oliveira DA. Impacto da cefaleia primária na qualidade de vida de policiais militares e sua relação com transtorno mental comum. Headache Medicine 2013; 4(4):96-101.

75. Costa PFFD, Santos SLD, Silva MSD, Gurgel IGD. Prevalência de transtorno mental comum entre trabalhadores canavieiros. Rev Saude Publica 2017; 51:113.
76. Faria NM, Facchini LA, Fassa AG, Tomasi E. Estudo transversal sobre saúde mental de agricultores da Serra Gaúcha (Brasil). Rev Saude Publica 1999; 33(4):391-400.

77. Morin PV, Stumm EMF. Transtornos mentais comuns em agricultores, relação com agrotóxicos, sintomas físicos e doenças preexistentes. Psico 2018; 49(2):196205.

78. Mota CA, Silva AKLD, Amorim K. Prevalência de transtornos mentais comuns em servidores técnico -administrativos em educação. Rev Psicol Organ Trab 2020; 20(1):891-898.

79. Alexandre GC, Nadanovsky P, Lopes CS, Faerstein E. Prevalência e fatores associados à ocorrência da dor de dente que impediu a realização de tarefas habituais em uma população de funcionários públicos no Rio de Janeiro, Brasil. Cad Saude Publica 2006; 22(5):1073-1078.

80. Fernandes RDCP, Silvany Neto AM, Sena GDM, Leal ADS, Carneiro CAP, Costa FPMD. Trabalho e cárcere: um estudo com agentes penitenciários da Região Metropolitana de Salvador, Brasil. Cad Saude Publica 2002; 18(3):807-816.

81. Lima AIO, Dimenstein M, Figueiró R, Leite J, Dantas C. Prevalência de Transtornos Mentais Comuns e Uso de Álcool e Drogas entre Agentes Penitenciários. Psic Teor e Pesq 2019; 35:e3555.

82. Reichert FF, Lopes M, Loch MR, Romanzini M. Atividade Física e outros aspectos relacionados à saúde de Agentes Penitenciários de Londrina-PR. Rev Bras Ativ Fis Saúde 2007; 12(3):4-11.

83. Portz RM, Amazarray MR. Transtornos mentais comuns e fatores associados em trabalhadores bancários do Rio Grande do Sul, Brasil. Rev Psicol Organ Trab 2019; 19(1):515-522.

84. Silva LS, Barreto SM. Adverse psychosocial working conditions and minor psychiatric disorders among bank workers. BMC Public Health 2010; 10:686.

85. Marconato CDS, Magnago ACDS, Magnano TSBDS, Dalmolin GDL, Andolhe R, Tavares JP. Prevalência e fatores associados aos distúrbios psíquicos menores em trabalhadores do serviço hospitalar de limpeza. Rev Esc Enferm USP 2017; 51:e03239.

86. Rocha MRA, Marin MJS, Macías-Seda J. Factors associated with common mental disorders in a hospital cleaning staff. Rev Rene 2019; 20:e40861.

87. Martins LCX, Lopes CS. Military hierarchy, job stress and mental health in peacetime. Occup Med 2012; 62(3):182-187.

88. Martins LCX, Kuhn L. Prevalência de transtornos mentais comuns em jovens brasileiros recém-incorporados ao Serviço Militar Obrigatório e fatores associados. Cien Saude Colet 2013; 18(6):1809-1816.

89. Feijo D, Luiz RR, Camara VM. Common mental disorders among civil aviation flight attendants. Aviat Space Environ Med 2014; 85(4):433-439.

90. Oliveira GF, Carreiro GSP, Filha MDOF, Lazarte R, Vianna RPT. Risco para depressão, ansiedade e alcoolismo entre trabalhadores informais. Rev Eletr Enf 2010; 12(2):272-277.

91. Silva TMD, Aguiar OBD, Fonseca MDJMD. Associação entre sobrepeso, obesidade e transtornos mentais comuns em nutricionistas. J Bras Psiquiatr 2015; 64(1):24-31. 
92. Silva MC, Fassa AG, Kriebel D. Minor psychiatric disorders among Brazilian ragpickers: a cross-sectional study. Environ Health 2006; 5:17.

93. Souza SFD, Carvalho FM, Araújo TMD, Porto LA. Fatores psicossociais do trabalho e transtornos mentais comuns em eletricitários. Rev Saude Publica 2010; 44(4):710-717.

94. Faoro MW, Olinto MTA, Paniz VMV, Macagnan J, Henn RL, Garcez A, Pattussi MP. Dor musculoesquelética relacionada ao trabalho e sua associação com transtornos mentais comuns em trabalhadores de um frigorífico do Sul do Brasil. Rev Bras Med Trab 2018;16(2):136-144.

95. Brant LC, Dias EC. Trabalho e sofrimento em gestores de uma empresa pública em reestruturação. Cad Saude Publica 2004; 20(4):942-949.

96. Azevedo DSDSD, Lima EDP, Assunção AÁ. Fatores associados ao uso de medicamentos ansiolíticos entre bombeiros militares. Rev Bras Epidemiol 2019; 22:e190021.

97. Grittner AL, Walsh CA. The role of social stigma in the lives of female-identified sex workers: A scoping review. Sexuality \& Culture 2020; 24:1653-82.

98. Maciel RH, Santos JB, Matos TG, Meireles, GF, Vieira ME, Fontenelle M. Work, health and organisation of street scavengers in Fortaleza, Brazil. Policy and Practice in Health and Safety 2010; 8(2):95-112.

99. Goodwin L, Ben-Zion I, Fear NT, Hotopf M, Stansfeld SA, Wessely S. Are reports of psychological stress higher in occupational studies? A systematic review across occupational and population based studies. PloS One 2013, 8(11):e78693.

100. Silva MAD. Os reflexos da crise econômica sobre os direitos trabalhistas no Brasil. Rev Katál 2019; 22(2):252-272.

101. Ali GC, Ryan G, Silva MJ. Validated screening tools for common mental disorders in low- and middle-income countries: a systematic review. PloS One 2016;11(6): e0156939.

102. Egger M, Smith GD, Schneider M, Minder C. Bias in meta-analysis detected by a simple, graphical test. BMJ 1997;315(7109):629-634.

103. Mari JJ, Williams P. A validity study of a psychiatric screening questionnaire (SRQ-20) in primary care in the city of Sao Paulo. Br J Psychiatry 1986; 148(1):2326.

104. Gonçalves DM, Stein AT, Kapczinski F. Avaliação de desempenho do Self-Reporting Questionnaire como instrumento de rastreamento psiquiátrico: um estudo comparativo com o Structured Clinical Interview for DSM-IV-TR. Cad Saude Publica 2008; 24(2):380-390.

Article submitted 27/07/2020

Approved 22/02/2021

Final version submitted 24/02/2021

Chief editors: Romeu Gomes, Antônio Augusto Moura da Silva 
